\title{
Effect of Ethylenediaminetetraacetic Acid and Ammonium Oxalate on the Prevalence of Microorganisms and Removal of Aluminum in Soil by Bitter Leaf Plant (Vernonia amygdalina Delile)
}

\section{*11OMOREGBEE, O; IKHAJIAGBE, B; IGIEBOR, FA; CHUKWU, V; ANOLIEFO, GO}

\author{
Environmental Biotechnology Sustainability Research Group \\ Dept. of Plant Biol. and Biotechnology, University of Benin, Benin City \\ *Corresponding Email: osazuwa.omoregbee@lifesci.uniben.edu, +2347031970383
}

\begin{abstract}
This research was carried out to investigate effect of ethylenediaminetetraacetic acid and ammonium oxalate on the prevalence of microorganisms and removal of aluminum in soil by bitter leaf plant (Vernonia amygdalina). The test plant was sown in aluminium-polluted soil (conc. $=150 \mathrm{mg} \mathrm{Al} \mathrm{kg}^{-1}$ soil). One gram of each chelating agent was dissolved in 1.5 litres of water and applied at different time intervals; application on a day prior to sowing of test plant in metal-polluted soil, application on the day of planting, application at one week after planting; at one month after planting. For the control soils, chelating agent were not added, although aluminium-contaminated. In the control, aluminium concentrations in leaf tissues were $16.20 \mathrm{mg} / \mathrm{kg}$ compared to a staggering $9.20 \mathrm{mg} / \mathrm{kg}$ in EW 1 and $5.24 \mathrm{mg} / \mathrm{kg}$ in OD1. However, heavy metal concentration of the leaves of Vernonia amygdalina in the control, EW1, EM1, OD-1 and OW1 were significantly similar $(\mathrm{P}>0.05)$. Concentration of aluminium in the stem tissues were also similar in ED1, EM1, OD-1, OD1 and OW1 ( $>0.05)$ were concentration ranged from $5.42 \mathrm{mg} / \mathrm{kg}$ to $7.98 \mathrm{mg} / \mathrm{kg}$. Compared to the control, aluminium concentration in stem tissues was $4.95 \mathrm{mg} / \mathrm{kg}$ comparable with $3.42 \mathrm{mg} / \mathrm{kg}$ in OM1. In the plant root, OD1 had the highest accumulation of aluminium in the root $(16.92 \mathrm{mg} / \mathrm{kg})$; however concentrations of aluminium in the roots were also statically similar in OW1 $(15.08 \mathrm{mg} / \mathrm{kg})$, OM1 $(13.84 \mathrm{mg} / \mathrm{kg})$, OD-1 $(14.72 \mathrm{mg} / \mathrm{kg})$, EM1 $(15.12 \mathrm{mg} / \mathrm{kg})$ and in the control $(13.52 \mathrm{mg} / \mathrm{kg})$. Results of the following also showed concentrations of residual aluminium in the soil ranging from $68.25 \mathrm{mg} / \mathrm{kg}$ in the control to $109.85 \mathrm{mg} / \mathrm{kg}$ in ED1 soil. After three months of planting, results show that the total bacteria count for ED1 $\left(5.3 \times 10^{4} \mathrm{cfu} / \mathrm{g}\right)$ had the highest while OM1 $(3.9 \times$ $\left.10^{3} \mathrm{cfu} / \mathrm{g}\right)$ had the lowest. For fungi isolates, the highest was control $\left(8.2 \times 10^{3} \mathrm{cfu} / \mathrm{g}\right)$ whereas the lowest were OD-1 $\left(6.8 \times 10^{2} \mathrm{cfu} / \mathrm{g}\right)$. The most prevalent microorganisms in the spiked soil with heavy metal are Bacillus subtilis represented in all the samples for bacteria while Aspergillus niger representing fungi. The perseverance of the test plant in the aluminium spiked soil is an indication of adaptation to the stress imposed by the concentration of aluminium in soil. In spite of the metal composition within the soil, it was observed that a number of microorganisms existed. This may therefore suggest a favourable environment for the microorganisms within the soil rhizospheric region of Vernonia amygdalina. () JASEM https://dx.doi.org/10.4314/jasem.v21i4.4
\end{abstract}

Keywords: EDTA, oxalate, aluminium, pollution, remediation, Vernonia amygdalina

Microorganisms and plants are usually used for the removal of heavy metals. Bioremediation which is a natural process and its importance to biodiversity (above or below the ground) is increasingly considered for clean-up of metal contaminated and polluted ecosystem (Akshata et al., 2012). All the metals are toxic, but some of these are useful in low concentration. These metal toxicity cause serious morbidity and mortality (Surajana et al., 2009). The bioavailability can be improved by addition of organic nutrients to the soil such as manure, compost, biosolids, which condition the soil and increases the fertility of soil (Jin et al., 2011). Bioremediation can be carried out both in aerobic and anaerobic condition but aerobic conditions prove to be faster compared to that of anaerobic condition (Akshata $e t$ al., 2012). The isolation of heavy metal resistant microorganisms and the understanding of the mechanisms they use in order to remove this kind of pollutants may contribute to the development of improved bioremediation processes (Akshata et al., 2012). Bioremediation is the use of biological interventions of biodiversity for mitigation of the environmental pollutants. Microflora associated with 
plants; endophytic bacteria, rhizosphere bacteria and mycorrhizae have the potential to degrade heavy metals in association with plants. Bioremediation, phytoremediation and rhizoremediation contribute significantly to the fate of hazardous waste (heavy metals) and can be used to remove these unwanted compounds from the biosphere. Bioremediation processes can be accessed through a multifaceted approach such as, Natural attenuation, sensing environmental pollution, metabolic pathway engineering, applying phyto and microbial diversity to problematic sites, plant-endophyte partnerships and systems biology (Asha and Sandeep, 2013). Enhancement of these polluted soil residues with different organic amendments like manure compost and biosolids will lead to increased bioavailability which in turn will act as nutrients for microorganisms and also a conditioner to improve the physical properties and fertility of the soils (Jin et al., 2010). The test plant for this study was Vernonia amygdalina Del., is a shrub or small tree. Vernonia amygdalina is a native African plant; which grows in most parts of Western and sub-Saharan Africa. The herb can be found growing naturally along the edges of agricultural fields and typically grows to a height of 2-5 m (6.6-16.4 ft). The leaves are elliptical and up to $20 \mathrm{~cm}$ ( $7.9 \mathrm{in})$ long. Its bark is rough (Sobukola et al., 2006; Ijeh and Ejike, 2011). The aim of this research is to evaluate the effects of collaboration of the chelating agent and the indigenous microorganisms in assistance to the remediation of aluminium spiked soil.

\section{MATERIALS AND METHODS}

Sun-dried top soil (Table 1) was obtained and made up to 20 kilograms $(\mathrm{kg})$ per bucket. The soil was polluted with aluminium (as Aluminum chloride), at a constant concentration of $150 \mathrm{mg} / \mathrm{kg}$. Relatively equal-sized stems cuttings of the Vernonia amygdalina (girth, $2.02 \pm 0.31 \mathrm{~cm}$; length $30.00 \pm 0.00$ $\mathrm{cm}$ ) were obtained for the study from a fallow area. Care was taken to ensure that the stem was devoid of injury prior to use. They were sown in the Alpolluted buckets by burying three-quarters of the stem length in soil at an angle $45^{\circ}$. The chelating agents were Ethylenediaminetetraacetic acid (EDTA) dichloride and Ammonium oxalate. One gram of each chelating agents was dissolved in 1.5 litres of water and applied at different time intervals to each bucket respectively. These intervals included EDTA or Oxalate application at a day before planting (ED-1 or OD-1, respectively); EDTA or oxalate application on the day of planting (ED1 or OD1, respectively); application at one week after planting (EW1 or OW1, respectively); and application at one month after planting (EM-1 or OM1, respectively). The experimental design was such that control soils were not chelated, although polluted with aluminum. Care was taken to ensure that the buckets were not perforated. This was to ensure that all HM contents remained unleached into surrounding soils, and that reduction in soil HM levels was attributed only to test plant or plant-related processes. Isolation and characterization of bacterial, fungal and actinomycete oil degraders was carried out using the methods of Cowan and Steel (1974); Sabba (1995); Cheesebrough, (1998); and Taiwo and Oso (2004).

\section{RESULTS AND DISCUSSION}

Table 1: Physicochemical properties of soil used in the experiment

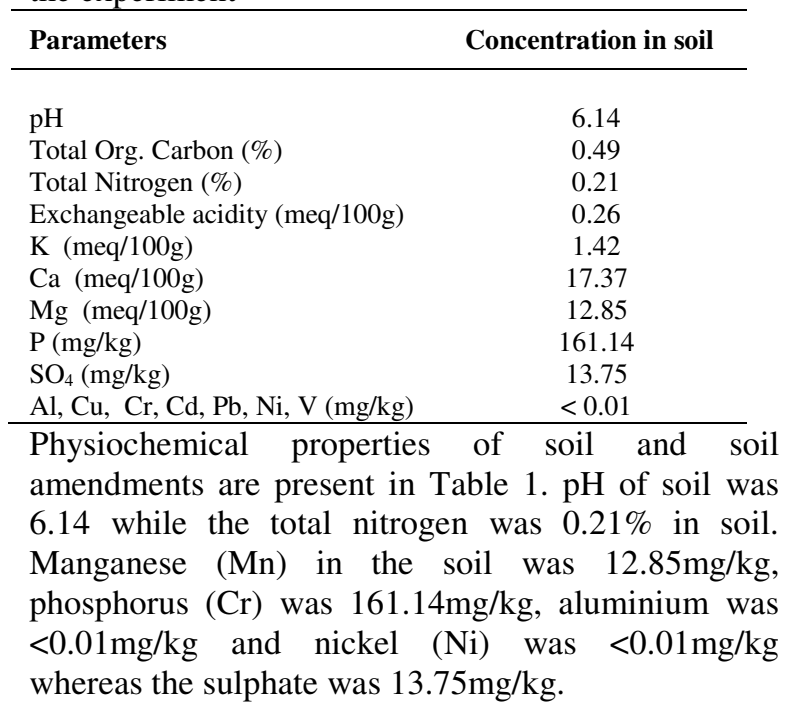

Table 2: The total colony count of microorganism

\begin{tabular}{ccc}
\hline Sample & Total Bacteria count $(\mathbf{c f u} / \mathbf{g})$ & Total Fungi count $(\mathbf{c f u} / \mathbf{g})$ \\
\cline { 2 - 3 } ED-1 & $37^{0} \mathrm{C}$ for 24 hours & $28^{0} \mathrm{C}$ for 72 hours \\
ED1 & $7.0 \times 10^{3}$ & $3.0 \times 10^{3}$ \\
EW1 & $5.3 \times 10^{4}$ & $1.2 \times 10^{3}$ \\
EM1 & $2.8 \times 10^{4}$ & $1.8 \times 10^{3}$ \\
Control & $1.0 \times 10^{4}$ & $2.1 \times 10^{3}$ \\
OD-1 & $2.4 \times 10^{4}$ & $1.2 \times 10^{3}$ \\
OD1 & $1.2 \times 10^{4}$ & $6.8 \times 10^{2}$ \\
OW1 & $8.0 \times 10^{3}$ & $1.3 \times 10^{3}$ \\
OM1 & $1.6 \times 10^{4}$ & $7.5 \times 10^{2}$ \\
\hline
\end{tabular}


$C f u / g=$ colony forming unit per gram, ED-1 = EDTA applied a day before planting, ED1 = EDTA applied on the day of planting. EWI=EDTA applied a week after planting, EM1=EDTA applied a month after planting, OD-1=Oxalate applied a day before planting, ODI=Oxalate applied on the day of planting, OWI=Oxalate applied $a$ week after planting, OMI=Oxalate applied $a$ month after planting

Table 3: Bacteria composition of aluminum spiked soil at 3 months after pollution

\begin{tabular}{lcccccccccc}
\hline \multicolumn{1}{c}{ Bacteria isolates } & ED-1 & ED1 & EW1 & EM1 & Control & OD-1 & OD1 & OW1 & OM1 \\
\hline $\begin{array}{l}\text { Proteus mirabilis } \\
\text { Pseudomonas aeruginosa }\end{array}$ & + & - & + & + & - & + & + & + & - & + \\
Micrococcus & - & + & - & - & + & + & - & - & + \\
Letus & & & & & & & & & \\
Bacillus subtilis & + & + & + & + & + & + & + & + & + \\
Enterobacter aerogenre & - & - & - & - & + & - & - & - & - \\
Proteus vulgaris & - & - & + & - & + & - & + & - & + \\
\hline
\end{tabular}

+ present, - absent. ED-1 = EDTA applied a day before planting, ED1 = EDTA applied on the day of planting. $E W 1=$ EDTA applied a week after planting, EMI=EDTA applied a month after planting, OD-1=Oxalate applied a day before planting, ODI=Oxalate applied on the day of planting, OW1=Oxalate applied a week after planting, OMI=Oxalate applied $a$ month after planting

Table 4: Fungi composition of aluminum spiked soil at 3 months after pollution

\begin{tabular}{lccccccccc}
\hline Fungi Isolates & $\mathbf{E D}_{\mathbf{1}}$ & $\mathbf{E D}_{\mathbf{2}}$ & $\mathbf{E D}_{\mathbf{3}}$ & $\mathbf{E D}_{\mathbf{4}}$ & Control & $\mathbf{O}_{\mathbf{1}}$ & $\mathbf{O}_{\mathbf{2}}$ & $\mathbf{O}_{\mathbf{3}}$ & $\mathbf{O}_{4}$ \\
\hline Aspergillus flavus & + & + & - & + & + & + & - & + & + \\
Mucor spp & + & + & + & - & + & + & - & + & + \\
Aspergillus carmari & - & - & + & - & + & - & + & + & - \\
Aspergillus niger & + & + & + & + & + & + & + & + & + \\
Penicillium notatum & + & - & - & - & + & - & - & - & - \\
Tricoderma spp & - & + & - & + & + & - & + & + & + \\
Rhizopus spp & + & - & + & - & - & + & + & - & -
\end{tabular}

+ present, - absent. ED-1 = EDTA applied a day before planting, ED1 = EDTA applied on the day of planting. $E W 1=$ EDTA applied a week after planting, EM1=EDTA applied a month after planting, OD-1=Oxalate applied a day before planting, ODI=Oxalate applied on the day of planting, OWI=Oxalate applied a week after planting, OMI=Oxalate applied $a$ month after planting

Table 5: Concentration of aluminum in plant tissues of Vernonia amygdalina and residual soil composition after plant exposure for 3 months

\begin{tabular}{|c|c|c|c|c|c|c|c|c|c|}
\hline Treatment & $\mathrm{C}$ & ED-1 & ED1 & EW1 & EM1 & OD-1 & OD1 & OW1 & OM1 \\
\hline \multicolumn{10}{|c|}{ Metal concentrations $(\mathrm{mg} / \mathrm{kg})$} \\
\hline Leaves & $6.20^{\mathrm{ab}}$ & NA & NA & $9.20^{\mathrm{a}}$ & $6.85^{\mathrm{ab}}$ & $8.14^{\mathrm{ab}}$ & $5.24^{\mathrm{b}}$ & $7.18^{\mathrm{ab}}$ & $5.44^{\mathrm{b}}$ \\
\hline Stem & $4.95^{\mathrm{b}}$ & NA & NA & $7.95^{\mathrm{a}}$ & $7.03^{\mathrm{a}}$ & $7.98^{\mathrm{a}}$ & $6.83^{\mathrm{ab}}$ & $5.42^{\mathrm{ab}}$ & $3.42^{\mathrm{b}}$ \\
\hline Soil & $68.25^{\mathrm{d}}$ & $102.20^{\mathrm{ab}}$ & $109.85^{\mathrm{a}}$ & 85.30 & $93.24^{\mathrm{bc}}$ & $78.28^{\mathrm{cd}}$ & $82.05^{\mathrm{cd}}$ & $79.19^{\mathrm{cd}}$ & $87.98^{b}$ \\
\hline \multicolumn{10}{|c|}{ Remediation Factors } \\
\hline BQ & 0.36 & NA & NA & 0.35 & 0.31 & 0.39 & 0.35 & 0.35 & 0.26 \\
\hline SRR & 0.82 & NA & NA & 1.37 & 0.91 & 1.09 & 0.71 & 0.84 & 0.64 \\
\hline ExC & 0.16 & NA & NA & 0.20 & 0.15 & 0.21 & 0.15 & 0.16 & 0.10 \\
\hline
\end{tabular}

BQ, Bioaccumulation quotient; SRR, Shoot-root ratio; ExC, Extraction coefficient. If SRR > 1, or ExC > 1, then a hyperaccumulator (Rotkittikhunetal.,2006; Harrison and Chirgawi, 1989). If BQ $>1$ the plant significantly bioaccumulated metal. NA, Not available for assay since plant was dead and unavailable at 12 weeks. Means on the same row with similar alphabetic superscripts do not differ from each other $(\mathrm{P}>0.05)$. $\mathrm{C}$ control; ED-1= EDTA added to soil 1 day before sowing of test plant; ED1= EDTA added 1 day after sowing; EW1= EDTA added 1 week after sowing; EM1= EDTA added 1 month after sowing. OD-1, OD1, OW1, OM1 represent application of Oxalate as described like EDTA.

Table 1 shows the physiochemical properties of soil and soil amendments are present in Table $1 . \mathrm{pH}$ of soil was 6.14 while the total nitrogen was $0.21 \%$ in soil. Manganese $(\mathrm{Mn})$ in the soil was $12.85 \mathrm{mg} / \mathrm{kg}$, phosphorus $(\mathrm{Cr})$ was $161.14 \mathrm{mg} / \mathrm{kg}$, aluminium was $<0.01 \mathrm{mg} / \mathrm{kg}$ and nickel (Ni) was $<0.01 \mathrm{mg} / \mathrm{kg}$ whereas the sulphate was $13.75 \mathrm{mg} / \mathrm{kg}$. The colony counts of isolated microorganisms were represented in Table 2. It was observed that the total bacteria count for ED1 $\left(5.3 \times 10^{4} \mathrm{cfu} / \mathrm{g}\right)$ was the highest followed by OM1 $\left(3.9 \times 10^{4} \mathrm{cfu} / \mathrm{g}\right), \mathrm{EW} 1\left(2.8 \times 10^{4}\right.$ $\mathrm{cfu} / \mathrm{g})$ and control $\left(2.4 \times 10^{4} \mathrm{cfu} / \mathrm{g}\right)$ respectively while the samples with the lowest values were ED-1 $(7.0 \times$ $\left.10^{3} \mathrm{cfu} / \mathrm{g}\right)$ and OM1 $\left(3.9 \times 10^{3} \mathrm{cfu} / \mathrm{g}\right)$. For fungi isolates, control $\left(8.2 \times 10^{3} \mathrm{cfu} / \mathrm{g}\right)$ had the highest value followed by ED-1 $\left(3.0 \times 10^{3} \mathrm{cfu} / \mathrm{g}\right)$ while the 
lowest were OD-1 $\left(6.8 \times 10^{2} \mathrm{cfu} / \mathrm{g}\right)$ and OW1 $(7.5 \times$ $10^{2} \mathrm{cfu} / \mathrm{g}$ ) (Table 2). In this study, microorganisms isolated from the soil samples include bacteria which are Bacillus substilis, Micrococcus luteus, Pseudomonas aeruginosa, Enterobacter aerogenre, Proteus vulgaris (Table 3) and fungal species which include Aspergillus niger, Aspergillus flavus, Rhizopus sp., Penicillium natatum, Mucor spp., Aspergillus carmari and Tricoderma spp (Table 4).

Table 5 shows concentration of aluminium in plant tissues of Vernonia amygdalina and residual soil composition after plant exposure for 3 months. In the control, aluminium concentrations in leaf tissues were $16.20 \mathrm{mg} / \mathrm{kg}$ compared to a staggering $9.20 \mathrm{mg} / \mathrm{kg}$ in EW1 and $5.24 \mathrm{mg} / \mathrm{kg}$ in OD1. However, heavy metal concentration of the leaves of Vernonia amygdalina in the control, EW1, EM1, OD-1 and OW1 were significantly similar $(\mathrm{P}>0.05)$. Concentration of aluminium in the stem tissues were also similar in ED1, EM1, OD-1, OD1 and OW1 $(P>0.05)$ were concentration ranged from $5.42 \mathrm{mg} / \mathrm{kg}$ to $7.98 \mathrm{mg} / \mathrm{kg}$. Compared to the control, aluminium concentration in stem tissues was $4.95 \mathrm{mg} / \mathrm{kg}$ comparable with $3.42 \mathrm{mg} / \mathrm{kg}$ in OM1.

In the plant root, OD1 had the highest accumulation of aluminium in the root $(16.92 \mathrm{mg} / \mathrm{kg})$; however concentrations of aluminium in the roots were also statically similar in OW1 $(15.08 \mathrm{mg} / \mathrm{kg}), \quad$ OM1 $(13.84 \mathrm{mg} / \mathrm{kg}), \quad$ OD-1 $\quad(14.72 \mathrm{mg} / \mathrm{kg}), \quad$ EM1 $(15.12 \mathrm{mg} / \mathrm{kg})$ and in the control $(13.52 \mathrm{mg} / \mathrm{kg})$. Results of the following also showed concentrations of residual aluminium in the soil ranging from $68.25 \mathrm{mg} / \mathrm{kg}$ in the control to $109.85 \mathrm{mg} / \mathrm{kg}$ in ED1 soil. It should be noted at this junction that total plants concentrations of the metals was higher in OD1 where value was $30.84 \mathrm{mg} / \mathrm{kg}$ followed by EM1 where total accumulation was $39.06 \mathrm{mg} / \mathrm{kg}$ and the least was obtained in OM1. Considering the remediation factors bioaccumulation factors ranged from 0.26 to 0.39 . Because BQ was generally less than 1 it implied that the test plant bitter leaf did not significantly accumulate aluminium in it plant parts. The shoot to root ratio value showed that plants in both EWI and OD-1 haven accumulated values that were greater than 1 implied that they were hyperaccumulators of aluminium. In OD-1 where the SRR was 1.09 and EW1 where SRR was 1.37 it implied that they had SRR greater than 1. Finally using the extraction coefficient the plant did not have any value that was higher than 1 so that also implied that the plant could not hyperaccumulate.

This research explained more understanding on Vernonia amygdalina being a remediating plant through the collaboration of chelators and the indigenous microorganisms in assistance to the remediation of aluminium spiked soil. It is unattainable to completely describe the entire microflora of any soil in terms of biodiversity, quantity, ecological functions and microbe- microbe, microbe-soil, microbe-plant interrelationships. However, the typical composition of the microbial community is used to obtain conclusions on soil fertility and plant health. Without its microbial content, soil would be the simple anchoring matrix for plants (Haferburg and Kothe, 2010). Even the nutrient supply grinds to a halt if replenishment of nutrients by microbial activity would not continue. Biological parameters seem to be the more trustworthy indicators to follow the development of soil treatment and extra functions of plant (Yakovchenko et al., 1996).

According to Rotkittikhun et al. (2006); Harrison and Chirgawi (1989), who stated that the when there is amendment of soil through bioaugumentation enables plants that are exposed to heavy metal (abiotic stress) to attain the possibility of being an hyperaccumulators of heavy metals at higher concentration. Therefore, it is expected that the assistance rendered by EDTA, Oxalate and soil microbes within the soil aided the plant by boosting its capability to hyperaccumulate.

The availability of heavy metals can be affected by microbes throughout metabolic activities directly or indirectly and this plays a crucial role in preserving soil function. Microbes in the soil play significant roles in recycling of plant nutrients, maintenance of soil structure, detoxification of noxious chemicals, and control of plant pests and plant growth (Elsgaard et al., 2001; Filip, 2002). The most prevalent microorganisms in soil that are spiked with heavy metal are Bacillus subtilis represented in all the samples for bacteria while Aspergillus niger representing fungi in all samples (Omoregbee et al., 2015).

The presence of microbial diversities is essential for an adequate biodegradation process and the organisms are habitually concentrated around the root surfaces in the rhizosphere region, within dead and living roots, on the particles of the soil, or among aggregates of soil particles (Ampofo, 2013). Bacteria in bioremediation are prolific. Bacteria belonging to the Pseudomonas and Bacillus species have these desirable characteristics, which are surviving abiotic stress created by heavy metal better than the types of bacteria that are naturally present in the polluted environment. They assist the test plant by growing 
and reproducing easily. Many times they are nonpathogenic, and do not generate gases that are toxic or not pleasant to the environment (Efeovbokhan et al., 2012).

Two isolates of predominant fungi belonging to the Aspergillus genera shows multi-metal resistance with varying level and it seems that continuous exposure of the these fungi against heavy metals might have exerted selection pressure on soil fungal population resulting in the development of multimetal resistant fungi. Result from this research showed that the Aspergillus sp. biomass had a higher adsorption capacity than other fungi present. The differences may be ascribed to its chemical composition of the cell wall leading to various types of interaction of metals with the available fungi that is the fundamental ability of this organism (Gadd, 1993 and Ahmad et al., 2005).

Several authors have reported that the remediative ability of live biomass of the various filamentous fungi remediating varieties of metals like $\mathrm{Zn}, \mathrm{Ni}, \mathrm{Cd}$, $\mathrm{Al}, \mathrm{Cu}, \mathrm{Co}$ but less commonly to chromium. However certain others authors reported the bioadsorption ability of dead/living biomass of Aspergillus sp. other fungi (Bai and Abraham, 2001; Teskova and Petrov, 2002; Ahmad et al., 2005). This could be that soil fungi of metal polluted soil have developed tolerance to toxic metals and probably increased metal biosorption capacity with the assistance of chelating agent introduced to the soil. Also, the release of enzymes by the plant can as well be a factor for the survival of effectiveness of these microorganisms found around the rhizospheric region of the plant.

Conclusion: The persistence of the test plant in the aluminum spiked soil is an indication of adaptation to the abiotic stress imposed by the aluminum in the soil. In spite of the metal composition within the soil, it was observed that a number of microorganisms existed. This may therefore suggest that the plant provides a favourable environment for the microorganisms within the soil region to survive. The survival mechanisms adapted by Vernonia amygdalina confirms the notion that assistance derived by the plant through collaboration with the chelating agent and establishing the plant-microbial interactions increases the phytoaccumulating ability of Vernonia amygdalina.

\section{REFERENCES}

Ahmad, I., Zafar, S. and Ahmad, F. (2005). Heavy metal biosorption potential of Aspergillus and Rhizopus sp. isolated from wastewater treated soil. Journal Applied Science Environmental Management 9 (1) 123-126.

Akshata, J. N., Udayashankara, T. H. and Lokesh K. S. (2012). Review on Bioremediation of Heavy Metals with Microbial Isolates and Amendments on Soil Residue. International Journal of Science and research 3(8): 118-123.

Ampofo, J.A. (2013). Agrochemicals and bacterial diversity in cultivated tropical soils Chapter one of Herbicides Advances in Research. Eds. A. J. Price and J. A. Kelton. 17p.

Asha, L. P. and Sandeep, R. S. (2013). Review on Bioremediation- Potential Tool for Removing Environmental Pollution. International Journal of Basic and Applied Chemical Sciences 3(3):21-33.

Bai, S. and Abraham, T.E. (2001). Biosorption of chromium (VI) from aqueous solution by Rhizopus nigricans. Bioresource Technology 79: 73-81.

Cheesebrough, M. (1998) .District Laboratory Practice in Tropical Countries, part II (Microbiology). Cambridgeshire Tropical Health Technology, Cambridge, United Kingdom. 231.

Cowan, S. T. and Steele, K. J., (1974). Manual for Identification of Medical Bacteria. 2nd. Ed., Cambridge University Press, Cambridge, United Kingdom. 216p.

Efeovbokhan, V.E., Hymore, F.K. and Oyakhire, C.T.G. (2012). The Effects of Pseudomonas aeroginosa and Aspergillus niger on the Bioremediation of Raw and Treated Crude Oil Polluted Water. International Journal of Science and Technology 2(6): 2224-3577.

Elsgaard, L., Petersen, S.O. and Debosz, K. (2001). Effects and risk assessment of linear alkylbenzene sulfonates in agricultural soil. 1. Short-term effects on soil microbiology. Environmental Toxicology and Chemistry 20(8):1656-1663.

Filip, Z. (2002). International approach to assessing soil quality by ecologically-related biological parameters. Agricultural Ecosystem and Environment 88(2):689-712.

Gadd, G.M. (1993). Interaction of fungi with toxic metals. New Phytology 124: 25-60. 
Haferburg, G. and Kothe, E. (2010). Metallomics: lessons for metalliferous soil remediation. Applied Microbiology and Biotechnology 87:1271-1280.

Ijeh, I.I. and Ejike, C.E.C.C. (2011). Current perspectives on the medicinal potential of Vernonia amygdalina Del. Journal of Medicinal Plant Research 5 (7): 1051-1061.

Jin, H. P., Dane, L., Periyasamy, P., Girish, C., Nanthi, B. and Jae-Woo, C. (2011). Role of organic amendments on enhanced bioremediation of heavy metal(loid) contaminated soils. Journal of Hazardous Materials 185 (2-3):549-574.

Omoregbee, O., Ikhajiagbe, B. and Udinyiwe C. O. (2015). Studies of heavy metal contents and microbial composition of rhizosphere of Panicum maximum within and around auto mechanic workshop in Benin City. Journal of Applied Science and Environmental Management 19(2): 271-276.

Sabba, R.N.S (1995). Soil Microbiology: Soil Microorganism and Plant Growth. Oxford Publisher, New Delhi. 509p.
Sobukola O. P., Dairo O.U., Sanni L.O, Odunewu A. V. and Fafiolu B.O. (2006). Thin layer drying process of some leafy vegetables under open sun. International Journal of Food Science Technology 13(1):35-40.

Suranjana, A. R. and Manas, K. R. (2009). Bioremediation of Heavy metals Toxicity - with special Reference to Chromium, special. $A l$ Ameen Journal of Medical Sciences 2(2):57-63.

Taiwo, L.B. and Oso, B.A. (2004). Influence of composting techniques on microbial succession, temperature, and $\mathrm{pH}$ in a composting municipal solid waste. African Journal of Biotechnology 3:239-243.

Teskova, K. and Petrov, G. (2002). Removal of heavy metals from aqueous solution using Rhizopus delemar mycelia in free and polyurethane- bound form. Z. Naturforsch 57: 629.

Yakovchenko, V., Sikora, L.J. and Kaufman, D.D. (1996). A biologically based indicator of soil quality. Biological and Fertility of Soils 21:245251 